\title{
Study of the performance and emission characteristics for a dual fuel powered single cylinder diesel engine
}

\author{
Pankaj Dubey* and Rajesh Gupta \\ ${ }^{1}$ Department of Mechanical Engineering, MANIT Bhopal, \\ 462003, M.P. India \\ *Email: pankajdubey450@gmail.com \\ Phone: +919424747687
}

\begin{abstract}
In the present study, the performance of a new combination of biofuels jatropha biodiesel and turpentine oil for a diesel engine with a view to eliminate dependency on fossil fuel was observed. Jatropha biodiesel and turpentine oil are a high and low viscosity fuel combination with comparable heating values to that of diesel; this makes them conducive for in a diesel engine. The extensive experimental work was carried out on a Kirloskar make-single cylinder, constant speed, four strokes, 661cc diesel engine to examine the combustion performance and emission characteristics using the jatropha methyl-ester with turpentine oil and pure diesel. The engine was fuelled with the jatropha methyl-ester with turpentine oil (50\% - 50\% on a volume basis) blend run on different loading conditions from no load, 35\%, 65\%, and full load. The blend of a dual biofuel was prepared with the help of a magnetic stirrer at $40^{\circ} \mathrm{C}$ in the presence of a surfactant span 80. The dual fuel blend was found to be superior to the diesel fuel in all aspects such as performance and emissions. In a further full load condition, a decrease of $2.9 \%$ in the brake thermal efficiency and reduction of $41.6 \%, 3 \%$, and $4.43 \%$ in $\mathrm{CO}, \mathrm{NOx}$ and $\mathrm{CO}_{2}$ respectively were recorded while $\mathrm{HC}$ was found to increased $29.31 \%$.
\end{abstract}

Keywords: Dual biofuel, Turpentine oil, Jatropha Biodiesel, Emission, Diesel engine

\section{INTRODUCTION}

It was proven to be an uphill task for most of the emerging economies across the globe to cope with the growing demand of energy consumption while they focus on expanding the size of their gross domestic products (GDPs). It was estimated that there will be a phenomenal rise in energy consumption in the next three to four decades and expected that 2.3 billion population increase will further worsen the energy scenario, reaching $66 \%$ of the global population by 2030 [1-4]. This exorbitant rise in the power consumption is expected to be concentrated in the Latin America, Africa and the urban pockets of Asia. Rapid depletion of the natural energy resources such as fossil fuels and the ever growing concerns of environmental issues such as global warmingn have further constrained the issue of energy availability [5]. As such, the circumstances demand for new sources of energy that can fulfil the demand of energy, which is renewable, clean and pollution free. In this context, researchers, scientists, and engineers have come up with various alternate sources of fuel among which biodiesel is a viable substitute that can perhaps reduce the complexity of energy crisis to some coverage. It was proved by scientists that the characteristics of biodiesel are similar to the diesel fuel and can be used as its prominent substitute $[6,7]$. 
Over the past decade, an extensive research has taken place on various biodiesel derived from vegetable oils (both non-edible and edible) and animal fats in the form of methyl or ethyl ester of fatty acid [8-11]. The non-edible oils such as Pongamia pinnata (Karanj), Jatropha curcas (Ratanjyot), Calophyllum innophyllum (Nagchampa), turpentine oil etc. have also been used for biodiesel production. Biodiesel is a non-toxic, renewable, and biodegradable fuel, can either be used in diesel engines in pure or the form of blend without requiring any modifications to the engine. In general, biodiesel tends to improve performance and emission characteristics of diesel engines [2, 12-15]. However, such usage of biofuels in diesel engines has met various practical problems; e.g. high viscosity, polymerization during storage and combustion, gum formation due to oxidation, acid composition, free fatty acid content, lubricating oil thickening and carbon deposits which are amongst the various problems reported by Agrawal. Furthermore, he has suggested potential solutions to resolve these problems by preheating the fuel prior to injection, chemically alter the fuel to an ester or using lubricating oil as additive to inhibit oxidation. In addition to Jatropha, large numbers of other fuel substitutes have also been attempted. Some researchers have investigated the performance, combustion and emission characteristics of diesel engines using turpentine as a fuel [16]. Karthikeyan et al. [17]; experimentally examined the performance and emission characteristics of turpentine oil in diesel engines and reported performance improvement at $75 \%$ load condition, 40-45\% lower smoke, similar NOx emission, and 75\% diesel replacement with turpentine oil is possible with little engine modifications. Kaplan et al. [18] performed experiments on turpentine oil used as an additive with diesel fuel and the results indicate similar performance as that of diesel and lower exhaust emissions such as $\mathrm{CO}, \mathrm{HC}, \mathrm{NOx}$, $\mathrm{CO}_{2}$, and soot. Liaquat et al. [19] conducted an experiment on biodiesel derived from coconut and waste cooking oil blended with diesel. The results revealed a reduction in brake power, $\mathrm{HC}, \mathrm{CO}$ and $\mathrm{CO}_{2}$ emissions while $\mathrm{NOx}$ emission and specific fuel consumption increased. Bora et al. studied the performance and combustion emission characteristics of a diesel engine using dual fuel biodiesel (Rice bran oil, Palm oil, and Pongamia oil) and biogas. The result revealed higher $\mathrm{CO}, \mathrm{HC}$ and lower $\mathrm{CO}_{2}, \mathrm{NOx}$ and smoke emission with marginally lower thermal efficiency [20].

In the recent years, several experimental studies have focused on the dual fuel blends containing one or more biofuels forming a combination of biofuels with high and low viscosities so that the combined viscosity remains comparable with that of diesel [21, 22]. Experiments with various combinations of biodiesel-methanol, biodiesel-ethanol, cashew nut shell oil-camphor oil, biodiesel-eucalyptus oil etc. are in progress. In this context, Mohsin et al. [23] studied the effects of the biodiesel-CNG blend on engine performance and exhaust emission of a diesel engine dual fuel, and the results indicate better exhaust emission as well as improvement in the fuel economy as compared to the base fuel. Devan and Mahalaxmi [24] used a combination of eucalyptus oil and methyl ester derived from the paradise oil replacing conventional diesel completely; they reported improvements in emission levels and the performance was found comparable with pure diesel. Furthermore, the eucalyptus and pine oil also have lower viscosity but their heating values are simultaneously comparable to that of diesel; therefore, they can be used in the higher proportions as compared to the alcohols. Anand et al. [25] experimented with $10 \%$ methanol and $90 \%$ Karanj methyl ester in a place of diesel and observed improvement in the emission characteristics especially NOx and smoke, combustion, and performance of diesel engine. Vallinayagam et al. [26] investigated a dual bio-fuel (pine oil and kapok methyl-ester) strategy to eliminate diesel completely and reported that these fuels could be used directly in the diesel engines without any 
modifications and their emissions $\mathrm{HC}, \mathrm{CO}$ and smoke were reduced by $8.1 \%, 18.9 \%$ and $12.5 \%$ respectively at full load and NOx emission remained similar to the standard diesel. One of the major conclusions from the numerous investigations concentrating on the strategy of using biofuel having lower viscosity with either diesel or biodiesel in larger proportions essentially depends on the calorific value of the less viscous fuel component.

Table 1. Properties of less viscous biofuels.

\begin{tabular}{lllll}
\hline $\begin{array}{l}\text { S. } \\
\text { No. }\end{array}$ & Bio-fuel & $\begin{array}{l}\text { Viscosity } \\
\left(\mathrm{cSt} @ 40^{\circ} \mathrm{C}\right)\end{array}$ & $\begin{array}{l}\text { Calorific Value } \\
(\mathrm{KJ} / \mathrm{Kg})\end{array}$ & Reference \\
\hline 1 & Diesel & $3-4$ & 42700 & {$[24]$} \\
2 & Ethanol & 1.1 & 28600 & {$[27]$} \\
3 & Eucalyptus Oil & 2.0 & 43270 & {$[24]$} \\
4 & Methanol & 0.59 & 19800 & {$[27]$} \\
5 & Pine Oil & $1.3 @ 30^{\circ} \mathrm{C}$ & 42800 & {$[26]$} \\
6 & Turpentine Oil & $2.5 @ 30^{\circ} \mathrm{C}$ & 44400 & {$[17]$} \\
\hline
\end{tabular}

Thus, the alcoholic biofuels such as methanol and ethanol can only be used in smaller proportion because of their lower heating values and high latent heat of vaporization [28]. Table 1 shows the viscosity and heating values of some of the potential biofuels having a low viscosity which can be used with diesel or biodiesel. It is clear from the data enlisted in Table 1 that the properties of turpentine oil such as the heating value are being almost comparable to that of diesel and low viscosity making it a better candidate to be used with biodiesel. Although there have already been a significant amount of work done on the turpentine oil and diesel [29], the blending of jatropha biodiesel with turpentine oil has not been studied till now [15, 30-32]. In the present work, experiments on the blend of jatropha methyl-ester biodiesel and turpentine oil in 50:50 by volume proportions will be designed with a view to eliminating diesel completely yet the improvements in the engine performance and emission characteristics can be contemplated. In this study, the combustion, performance and emission characteristics will be comprehensively analysed and compared for a single cylinder diesel engine without any modification.

\section{MATERIALS AND METHODS}

\section{Jatropha Curcas}

Jatropha oil was distinguished as a prominent successor and alternative fuel for commercialization among various non-edible vegetable oils. Jatropha curcas is nonedible oil that can be grown on a huge-scale plantation on all types of land like deserts and wasteland and these plants can withstand adverse weather conditions [10, 31]. It is a perennial plant and drought-resistant, has a life span of fifty years and potential to grow on negligible soils. It needs very low sprinkling and grows in all kinds of soils (hill slopes, coastline areas). The yield of Jatropha seeds is about $0.8 \mathrm{~kg}$ per square meter per year [33]. Jatropha seeds contain oil ranges at 30 to $40 \%$ by weight and the kernel itself is ranged from $45 \%$ to $60 \%$ [34]. The basic restriction of this harvest is that the kernel is harmful and the oil cake cannot be used as mammal food. The oil cake can only be used as organic manure [35]. Some other researchers observed higher smoke, HC, CO and NOx emissions of the engine operating with jatropha oil [36, 37]. 


\section{Turpentine Oil}

Turpentine oil was first used in the domestic and industrial applications in the 1700s. Several studies have shown improved performance and emissions of diesel engines using the turpentine-diesel fuel blends. Turpentine oil is basically a biofuel that can easily be obtained from a resin, oleoresin, which in turn can be extracted from pine trees. Physically, it is a yellowish, opaque, colour less, odorous, and water-immiscible liquid. Chemically, the oil of turpentine is flammable, volatile and combustible; and it contains $\alpha$-pinene $40 \%$ by weight in turpentine. It is made up of $58-65 \% \gamma-$ pinene along with $\beta$ - pinene and other isometric terpenes. Owing to its prominent properties such as viscosity, calorific value, and low cetane number, it has adequate potential to reduce the dependency on conventional fossil fuels. Furthermore, due to its mixing ability with diesel in any proportion, it can be used as a supplement with diesel. It can prove as a better fuel substitute which can replace diesel due to its high production in the world. However, the higher cost of turpentine oil, as opposed to traditional diesel fuel, can easily be offset in favour of its low emission capability $[38,39]$. Turpentine has various advantages over diesel and it is possible to approximately have 60-65\% diesel replacement with turpentine in dual fuel mode with minor changes in the engine design. The performance indicators for turpentine oil such as specific fuel consumption, brake thermal efficiency, exhaust gas temperature and emission characteristics such NOx and smoke emission are found better to that of standard diesel fuel [40].

\section{Preparation of Jatropha and Turpentine biofuels}

\section{Transesterification Process}

The double transesterification process has been used to convert jatropha oil into Jatropha methyl ester. In the first pre-treatment process Jatropha oil was reacted with methanol in the presence of a catalyst $\left(\mathrm{H}_{2} \mathrm{SO}_{4}\right)$ to produce glycerol and fatty acid ester. The specified amount $500 \mathrm{ml}$ of Jatropha oil $100 \mathrm{ml}$ methanol and $4 \mathrm{ml}$ catalyst $\left(\mathrm{H}_{2} \mathrm{SO}_{4}\right)$ by volume ratio were put in a round bottom flask. The mixture was heated to $50^{\circ} \mathrm{C}$ and stirred $(2$ hours) till ester formation began and then cooled for about 18 hours at a separating flask without stirring. In the separating flask, two layers were formed. The top layer was the ester and bottom layer consisted of glycerol. In second post treatment process pre-treated Jatropha oil was reacted with methanol in the presence of a catalyst $(\mathrm{NaOH} / \mathrm{KOH})$ to produce glycerol and fatty acid ester. The specified amount $500 \mathrm{ml}$ of pre-treated Jatropha oil $100 \mathrm{ml}$ methanol and $4 \mathrm{gm}$ catalyst $(\mathrm{NaOH})$ by volume weight ratio were put in a round bottom flask and the same above process was applied until two layers were formed. The top layer was ester and bottom layer consisted of glycerol. The properties of the resulting Jatropha methyl-ester generally meet the ASTM standards [41, 42].

\section{Preparation of dual biofuel blend (BT50)}

The Jatropha biodiesel and Turpentine oil were blended at $50 \%-50 \%$ by volume ratio using a surfactant span 80 at $40^{\circ} \mathrm{C}$ about 1 hour with the help of a magnetic stirrer (homogenizer). A total 15 samples were prepared for the evaluation of stability properties using the equation given below:

$$
\text { Separated layer }(\%)=\frac{\text { Initial dual fuel blend }- \text { Final dual fuel blend }}{\text { Initial dual fuel blend }} \times 100
$$


The Jatropha biodiesel and turpentine oil blends were stabilised for two months under normal atmospheric circumstances. The properties of biofuel were determined by the ASTM methods is tabulated in Table 2.

Table 2. Properties of fuels.

\begin{tabular}{|c|c|c|c|c|c|}
\hline $\begin{array}{l}\text { S. } \\
\text { No. }\end{array}$ & Items & $\begin{array}{l}\text { Diesel } \\
\text { fuel }\end{array}$ & $\begin{array}{l}\text { Turpentine } \\
\text { oil }\end{array}$ & $\begin{array}{c}\text { Jatropha } \\
\text { Methyl ester }\end{array}$ & BT50 \\
\hline 1. & $\begin{array}{l}\text { Higher Calorific Value } \\
(\mathrm{kJ} / \mathrm{Kg})\end{array}$ & 43500 & 44400 & 39500 & 41950 \\
\hline 2. & 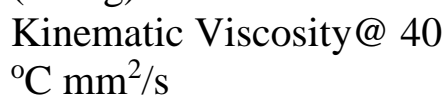 & 3.21 & 2.5 & 4.12 & 4.01 \\
\hline 3. & Specific Density $\left(\mathrm{Kg} / \mathrm{m}^{3}\right)$ & 0.831 & 0.920 & 0.881 & 0.900 \\
\hline 4. & Sulphur content & 340 & - & 8 & - \\
\hline 5. & Cloud point, ${ }^{\circ} \mathrm{C}$ & -12 & - & -4 & - \\
\hline 6. & Flash point, ${ }^{\circ} \mathrm{C}$ & 76 & 38 & 165 & - \\
\hline 7. & Pour point & -17 & - & -8 & - \\
\hline 8. & Cetane index & 47.14 & 38 & 48.13 & - \\
\hline 9. & $\begin{array}{l}\text { Latent heat of } \\
\text { vaporization }(\mathrm{kJ} / \mathrm{Kg})\end{array}$ & 230 & 285 & 320 & - \\
\hline
\end{tabular}

Table 3. Specification of fuel composition.

\begin{tabular}{lll}
\hline S. No. & Fuel & Fuel Blends \\
\hline 1 & Pure Diesel Fuel & PD \\
2 & $50 \%$ Jatropha+50\% Turpentine & BT50 \\
\hline
\end{tabular}

\section{EXPERIMENTAL SETUP}

The experiments were carried out on a single cylinder, direct injection, Kirloskar TV1, water cooled, and naturally aspirated engine. It was chosen for the existing investigation. This engine is mostly used for domestic electricity generations and agricultural activities. The schematic diagram of the experimental set up is shown in Figure 1. A layout of the experimental setup along with all instruments is shown in Figure 2. The Kistler makes the pressure sensor (response piezo electric) and TDC magnetic sensor with resolution 1 degree crank angle with time sampling 4 micro second calibrated by Legion Brothers were fitted at the cylinder head near the flywheel to measure the pressure of combustion chamber and crank angle at different engine loadings. The fuel injection system was the conventional, cam-driven, in-line (Pump-Line-Nozzle) fuel injection system which injects the fuel at 200-220 bars. The technical specifications of the engine are given in Table 4. A fuel tank of $5 \mathrm{~L}$ capacity was mounted at the back of a panel on the wall with the manual fuel consumption measuring burette which is nearer to the engine at the highest position. AVL CDS 250 exhaust gas analyser attached to a computer was used for the measurements of various exhaust gas parameters like $\mathrm{CO}, \mathrm{HC}, \mathrm{CO}_{2}$, and $\mathrm{NOx}$. The accuracy and reproducibility of the instrument were $1 \%$ of full-scale reading. A personal computer connected with the software 'DAQ factory software' was provided by Legion Brothers. The Legion data acquisition system has been used to record major parameters such as exhaust gas temperature, engine speed (rpm), in-cylinder gas pressure 
measurement, and crank angle measurement by TDC, heat release rate, and the engine power.

Table 4.Specifications of engine.

\begin{tabular}{ll}
\hline Model & TV1, Kirloskar oil Engine Ltd. India \\
\hline Type & Single Cylinder, Four stroke, water cooled, \\
& constant speed, vertical, direct injection, \\
& compression ignition engine, 661 cc \\
Bore & $87.5 \mathrm{~mm}$ \\
Stroke & $110 \mathrm{~mm}$ \\
Max power & $5.22 \mathrm{~kW}$ \\
Speed & $1500 \mathrm{rpm}$ \\
Compression ratio & $17.5: 1$ \\
Injection pressure & $210-220 \mathrm{bar}$ \\
Dynamometer & Eddy current \\
Pressure Sensor & Kistler \\
TDC at & 360 crank Angle \\
Start of Injection at & 337 degrees Crank Angle \\
\hline
\end{tabular}

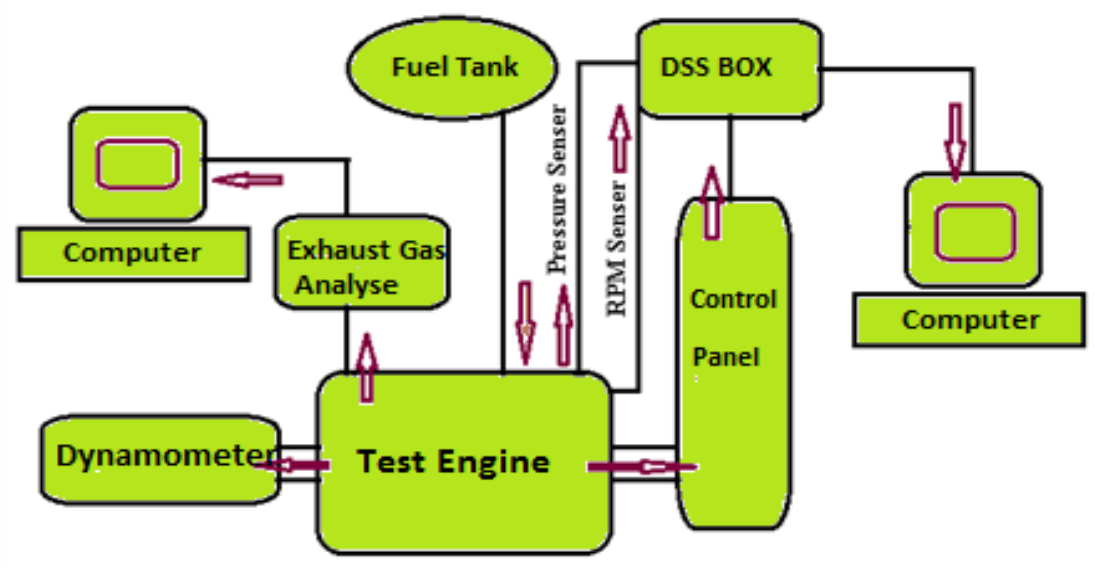

Figure 1. Schematic diagram of experimental set-up.

Table 5. List of instruments and its accuracy and percentage uncertainties.

\begin{tabular}{llll}
\hline S. No. & Instruments & Accuracy & Percentage Uncertainty \\
1. & AVL exhaust gas analyser & & \\
& CO & $\pm 0.02 \% \mathrm{vol}$ & \pm 0.2 \\
& NOx & $\pm 5 \mathrm{ppm}$ & \pm 0.1 \\
& $\mathrm{HC}$ & $\pm 4 \mathrm{ppm}$ & \pm 0.2 \\
& $\mathrm{CO}_{2}$ & $\pm 0.3 \% \mathrm{vol}$ & \pm 0.15 \\
2. & Speed measurement & $\pm 10 \mathrm{rpm}$ & \pm 0.1 \\
3. & Load Indicator & \pm 0.1 & \pm 0.2 \\
4. & Burette for fuel measurement & $\pm 0.2 \mathrm{cc}$ & \pm 1 \\
5. & Pressure measurement & $\pm 0.1-0.2$ & \pm 0.1 \\
\hline
\end{tabular}




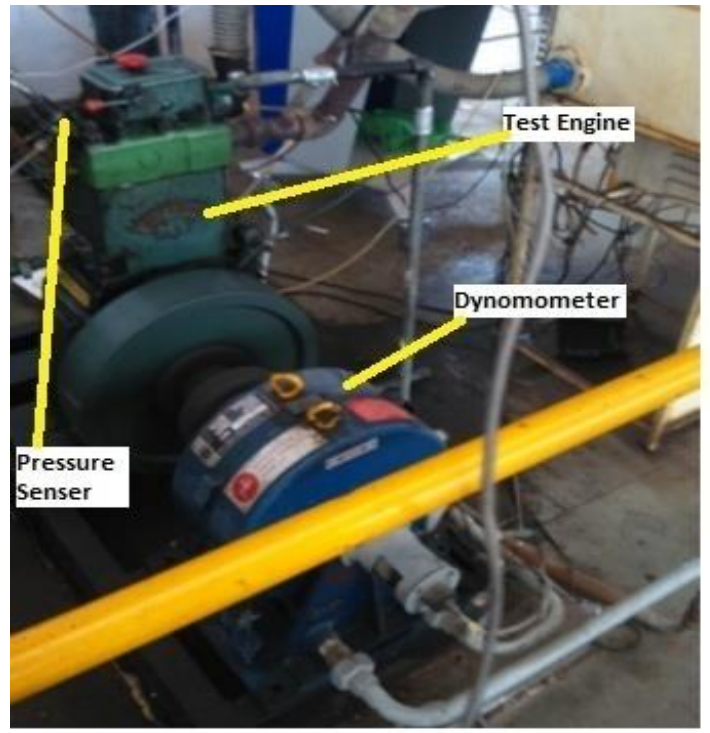

Experimental Setup

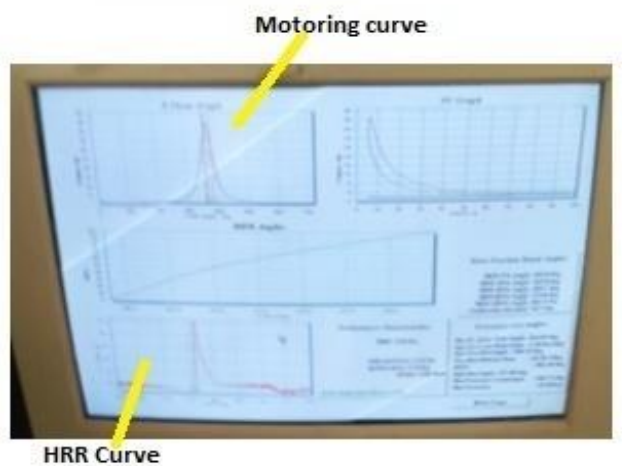

DAQ Software by Legion Brothers

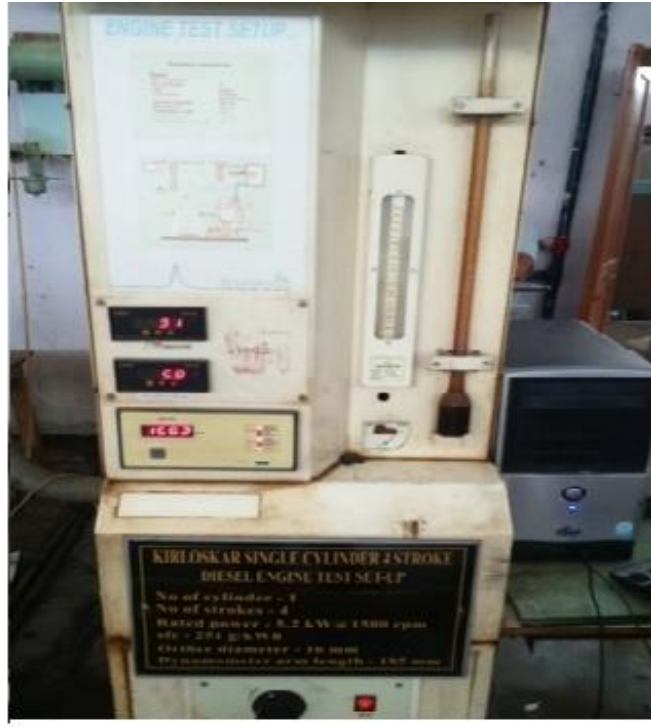

Control Panel

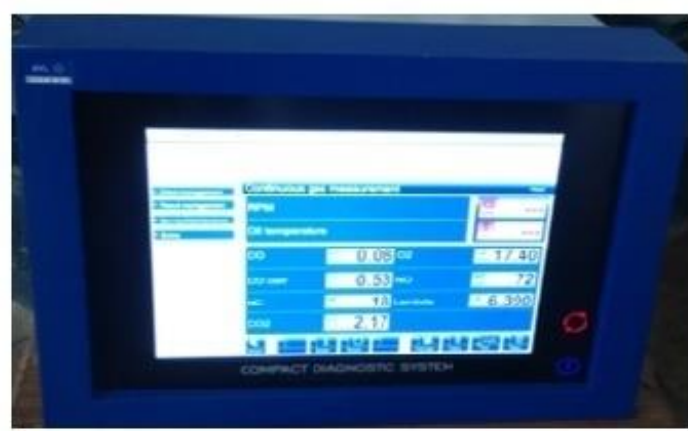

AVL CDS250 Exhaust Gas Analyser

Figure 2. A layout of the experimental setup.

To apply different engine loads an eddy current dynamometer (manual) maximum rated $7.5 \mathrm{~kW}$ power at 1500 to $3000 \mathrm{rpm}$ controlled by a switch provided in the control panel coupled with the engine. At the steady state condition, the data was collected and stored in the computer for post processing. The test was repeated to get the peak value so as to minimize the effect of fluctuations.

\section{RESULTS AND DISCUSSION}

The combustion phenomenon of internal compression engine depends on various parameters such as the fuel injection pressure, heat release rate, combustion duration, mixing of fuel with air, inlet temperature of the air, ignition delay and fuel properties like viscosity, calorific value, flash point, pour point, density, volatility etc. In the present investigation, experiments were carried out to estimate combustion, performance and emission parameters of a diesel engine by using dual fuel (Jatropha and turpentine oil) blend and mineral diesel. The blend of Jatropha methyl ester (50\%) and turpentine oil $(50 \%)$ known as a dual fuel was used and the experimental observations were collected to compare the combustion, performance and emission properties of blended fuel with a 
mineral diesel. The engine was loaded in the range of no load, $35 \%, 65 \%$, and full load for a constant speed of $1500 \mathrm{rpm}$.

\section{PERFORMANCE AND COMBUSTION TESTING}

\section{Heat Release Rate}

The comparison of heat release rate (HRR) for the conventional diesel fuel and dual fuel BT50 for various load conditions starting from no load to full load is presented in Figure 3. For BT50, the heat release rate qualitatively exhibited similar trend as that of conventional diesel fuel, however, the peak HRR was observed to be higher in magnitude for all load conditions as compared to the standard diesel because of the evaporation of turpentine oil in the cylinder resulted in higher ignition delay [8]. In Table 6 as well as Figure 3, it can be deduced that BT50 has a slightly higher ignition delay, thus, allowing more time for the fuel-air mixing with combustible limits subsequently leading to higher HRR during combustion. Furthermore, Figure 3 shows that the peak HRR magnitude reached 26.4, 42.4, 47.2 and $43.6 \mathrm{~J} / \mathrm{deg}$ crank angle at no load to full load condition respectively for the dual fuel blend. This is due to Jatropha biodiesel that has higher viscosity and low calorific value and turpentine oil has lower viscosity and higher calorific value which make up the deficiency of Jatropha biodiesel. The BT50 turpentine oil has fast burning capacity with high octane value, which induces faster burning resulting complete combustion in short duration. Figure 3(c) depicts BT50 at 65\% load which has ignition delay shorter (less than $1 \mathrm{deg}$ ) than standard diesel fuel due to the effective cetane rating of the BT50.

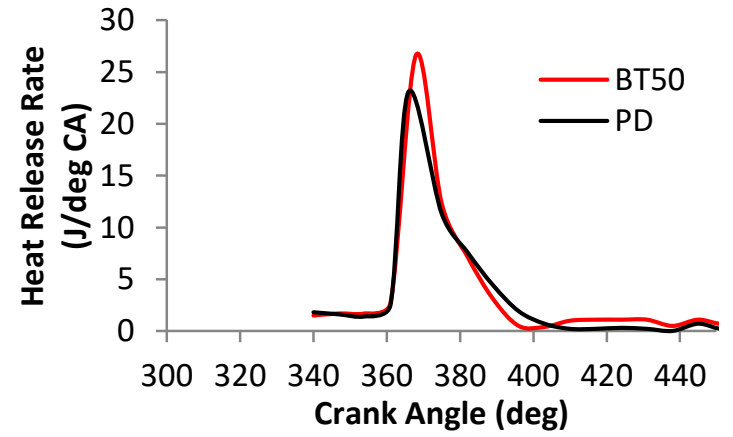

(a) No Load

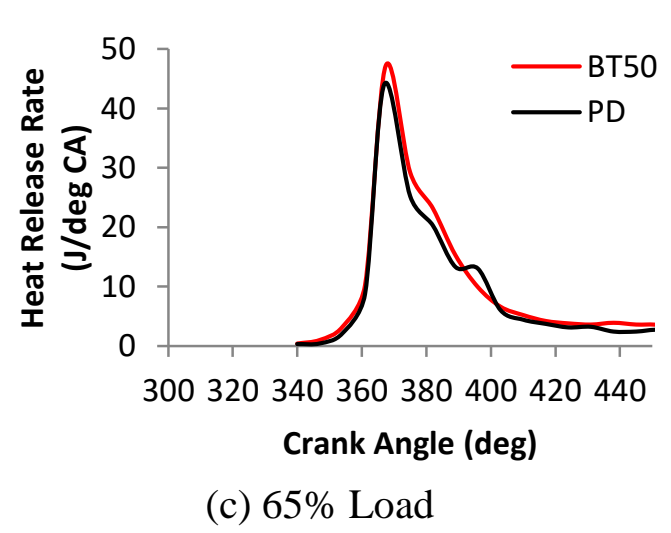

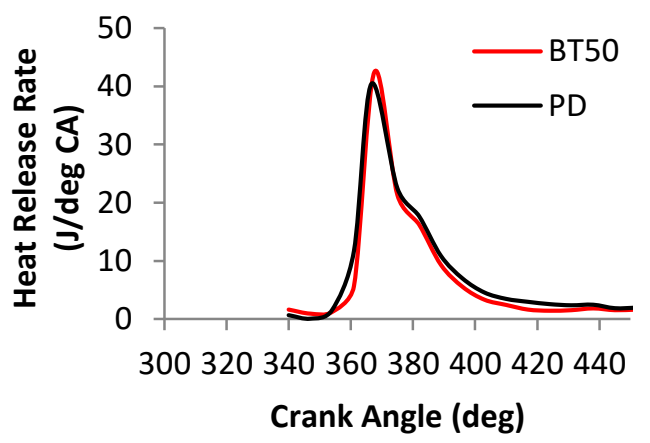

(b) $35 \%$ Load

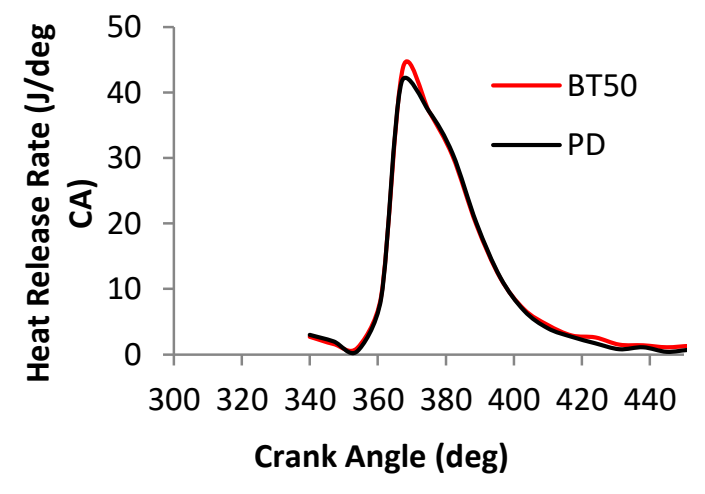

(d) Full Load

Figure 3. Heat release rate at engine power of (a) no load, (b) $35 \%$, (c) $65 \%$ and (d) full load. 


\section{In-Cylinder pressure}

Figure 4 depicts the in-cylinder pressure variation against the crank angle for various load conditions. The comparison of the in-cylinder pressure for the standard diesel and BT50 shows identical trends qualitatively. It can be observed that the magnitude of in-cylinder pressure for BT50 was higher than the standard diesel for all load conditions; the peak incylinder pressure was found to be 50 bars, 54 bars, 61 bars, and 60 bars for the dual fuel blend from no load to full load respectively. From Figure 4, it can be observed that the in-cylinder pressure was marginally higher compared to the standard diesel. It may be because the turpentine oil has higher octane fuel causing rapid evaporation by absorbing heat from the cylinder, therefore, leading to a higher in-cylinder pressure. The other reason behind this dual fuel blend exhibited marginal higher delay period than the diesel fuel, which was induced higher the in-cylinder pressure and marginal high HRR in all loads [16].

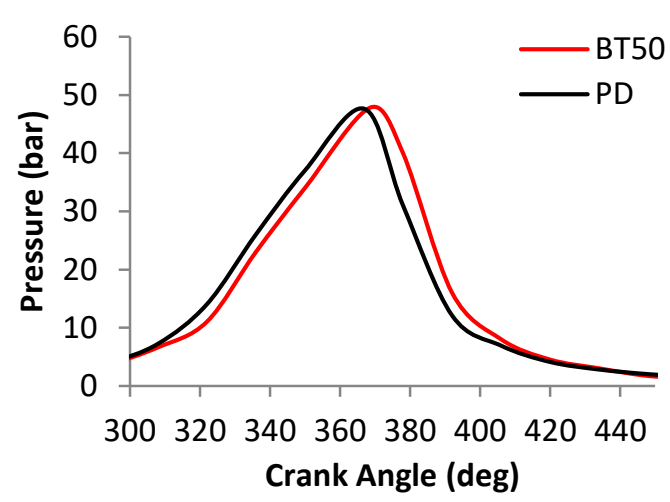

(a) No Load

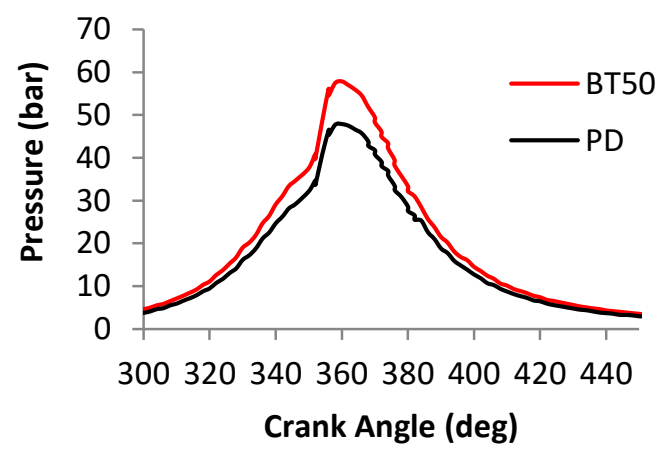

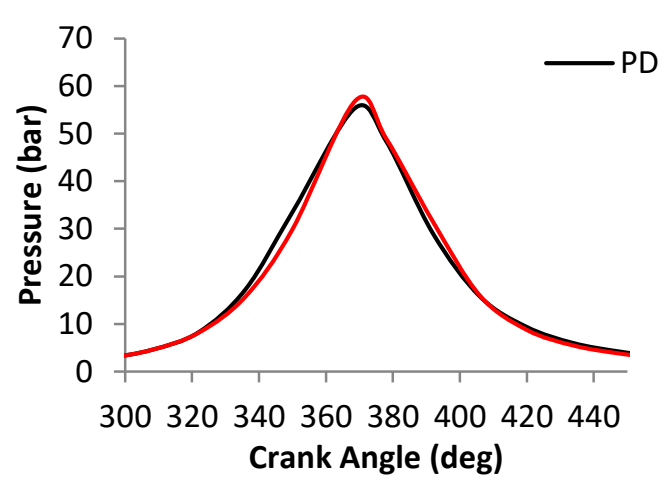

(b) $35 \%$ Load

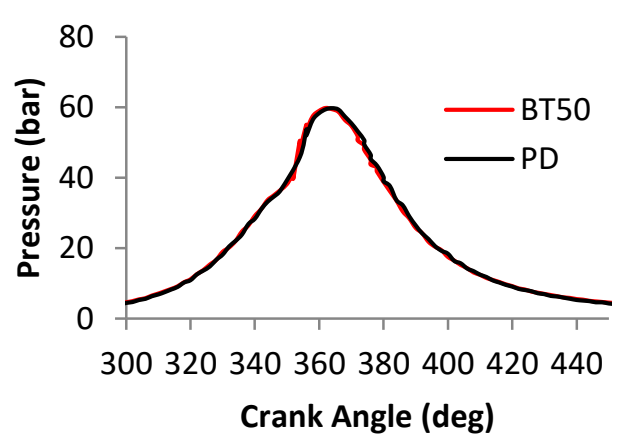

(c) $65 \%$ Load (d) Full Load

Figure 4. Comparison of the in-cylinder pressure at power of (a) no load, (b) 35\%, (c) $65 \%$ and (d) full load.

\section{Ignition Delay}

The ignition delay, which is an important design and performance parameters, is defined as the period between the start of fuel injection to the start of combustion. Some of the common variables that influence the ignition delay are the cetane number, fuel injection pressure, compression ratio, intake temperature, engine speed and air-fuel ratio. Table 6 describes the variation of ignition delay in terms of crank angles (deg) for various engine loads. It can be observed from Table 6 that the delay period decreased with the increasing 
engine load. The delay for dual fuel blend and standard diesel fuel were measured to be $16.9,16.9,15.9,16.2$, and 16.6, 16.4, 16.2, 16.1 crank angles respectively from no load to the full load. It may be due to the cetane rating of the fuel; standard diesel fuel has a higher cetane rating than the dual fuel blend. In addition to this, the temperature of combustion chamber also plays an important role in the fuel ignition. At low engine load, the ignition delay was observed to be on the higher side owing to the lower residual gas and wall temperatures, thus, causing a drop in the charge temperature at the time of fuel injection. Banapurmath et al. [43] who investigated the performance and emission properties of a diesel engine operated on Honge Jatropha and sesame oil reported the higher ignition delay was in the case of biodiesel and decreased with increasing of brake power from no load to full load.

Table 6. Comparison of ignition delay period.

\begin{tabular}{clll}
\hline \multirow{2}{*}{$\begin{array}{c}\text { S. } \\
\text { No. }\end{array}$} & $\begin{array}{c}\text { Load } \\
(\%)\end{array}$ & \multicolumn{2}{c}{ Delay Period $(\mathrm{deg})$} \\
\cline { 3 - 4 } & 0 & 16.6 & PD \\
\hline 1 & 0 & BT50 \\
2 & 35 & 16.4 & 16.9 \\
3 & 65 & 16.2 & 15.9 \\
4 & 100 & 16.1 & 16.2 \\
\hline
\end{tabular}

\section{Brake Specific Fuel Consumption}

The brake specific fuel consumption (BSFC) is typically used for evaluating the performance of an engine. Devan et al. [24] investigated the blend of the paradise oil $(50 \%)$ and eucalyptus oil (50\%) (lower and higher viscosity fuel) on a diesel engine also reported marginal higher BSFC. The dual fuel blend gives lower BSFC at higher load. This is because of better combustion of fuel at the higher engine load [33]. The BSFC was compared with the standard diesel at different loading conditions for the dual fuel blend BT50 as shown in Figure 5(a) at no to full load and the BT50 fuel consumption is marginally higher than the standard diesel fuel. This is mainly due to the combined effects of the relative fuel density and viscosity. Moreover, it may be due to higher calorific value and viscosity of turpentine oil, which compensated the properties of Jatropha biodiesel [38].

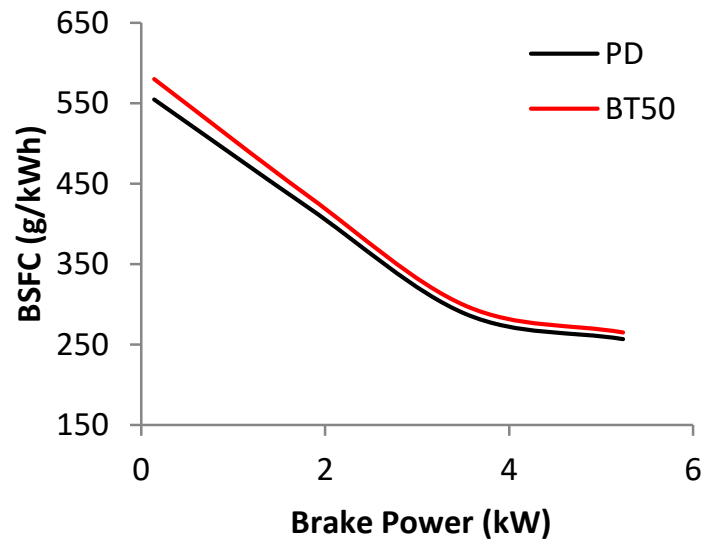

(a) BSFC

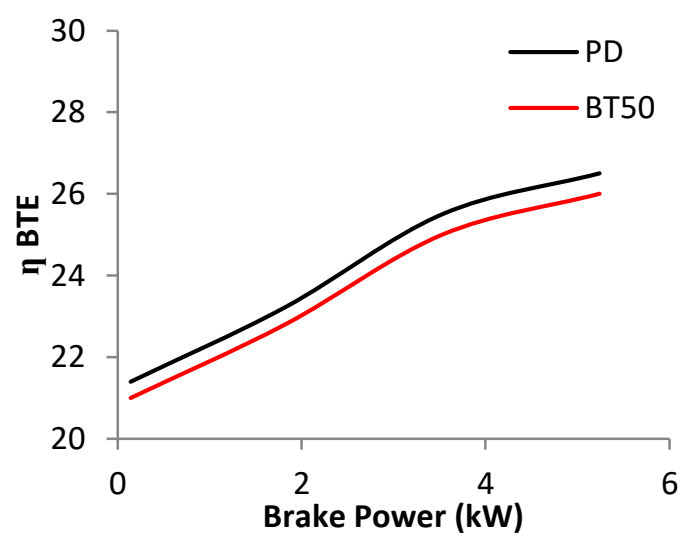

(b) BTE

Figure 5. Comparison of BSFC and BTE of diesel and BT50. 


\section{Brake Thermal Efficiency}

Brake thermal efficiency (BTE) of the engine indicates the fraction of fuel energy converted to the useful power output. Figure 5(b) illustrates the brake thermal efficiency with brake power output. From Figure 5(b), the dual biofuel blend exhibited lower BTE at no to full load condition than standard diesel fuel. It was due to the slower burning, low volatility, higher viscosity and density of Jatropha oil [43]. It was observed that BTE increased with the increasing of the brake power. The BTE improvement was due to the reduction in friction losses and increase in the brake power with the increase in load [44]. Among the fuel tested, the BTE was recorded for BT50 and standard diesel 21\%, 22.8\%, $25 \%, 26 \%$, and $21.4 \%, 23.22 \%, 25.5 \%, 26.5 \%$, respectively from no to full load. Hoque et al. [45] investigated the Performance and emission comparison of Karanja (pongamia pinnata), Pithraj (aphanamixis polystachya), Neem (azadira chtaindica) and Mahua (madhuca longofolia) seed oil on a diesel engine, resulted in lower BTE.

\section{EMISSION TESTING}

\section{NOx Emission}

Figure 6 (a) shows the comparison of NOx emissions of dual fuel blend and standard diesel fuel. The NOx emission in an idle condition was the same for the standard diesel as well as the Jatropha biodiesel - turpentine oil combination while NOx emission for dual fuel blend (BT50) were trivially lower as compared to the standard diesel at all loads. This may be attributed to the availability of oxygen for the dual fuel blend yielding lower NOx emissions. Incidentally, Vallinayagam et al. [26] also reported lower NOx while testing the pine oil and kapok methyl-ester oil on a diesel engine. Banapurmath et al. [43] who examined the performance and emission properties of a diesel engine run on Honge, Jatropha and sesame oil reported lower NOx emissions than the standard diesel fuel.

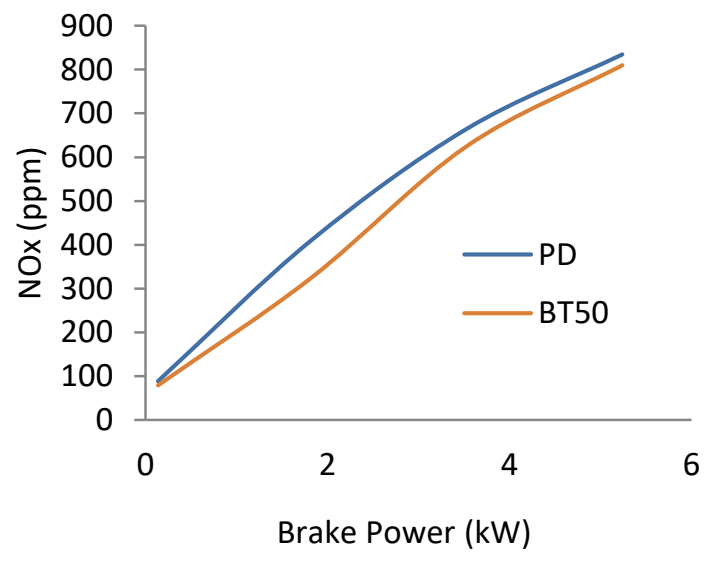

(a)

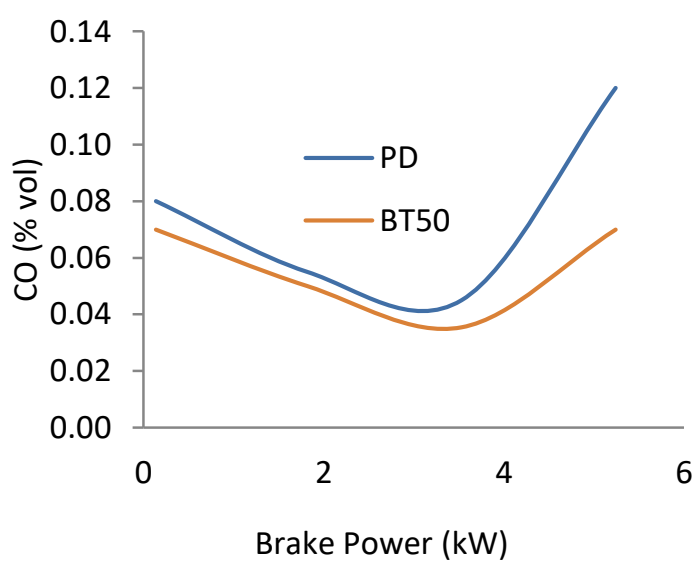

(b)

Fig. $6 \mathrm{NOx}$ and $\mathrm{CO}$ emissions at different engine power.

\section{CO Emission}

The CO emission of dual fuel blend and pure diesel fuel are shown in Figure 6(b) for various load conditions (no load, 35\%, 65\% and full load). Carbon monoxide is generally formed when there is insufficient oxygen to burn the fuel. Diesel engines generally work at excess air; therefore, diesel engines produce lower $\mathrm{CO}$ emissions than petrol engines [30]. It can be observed from Figure 6(b) that the $\mathrm{CO}$ emissions for the Dual fuel blend 
(BT50) were found to be lower than the diesel fuel, due to the availability of excess $\mathrm{O}_{2}$ and complete combustion of dual fuel blend. The $\mathrm{CO}$ emissions at full load condition were found to be $41.6 \%$ less as compared to the diesel fuel.

\section{$\mathrm{CO}_{2}$ Emission}

The variation of $\mathrm{CO}_{2}$ emission with respect to the brake power of a diesel engine at a constant speed of 1500 RPM is shown in Figure 7(a). The $\mathrm{CO}_{2}$ emission of pure diesel and dual fuel blend was found to increase with increasing load. At all load conditions, the $\mathrm{CO}_{2}$ emissions of dual fuel blend were lower than that of the pure diesel. The reduction of $\mathrm{CO}_{2}$ emission for BT50 dual fuel blend was found to be $13.3 \%, 13.6 \%, 11.2 \%$ and $4.4 \%$ at no load, $35 \%, 65 \%$ and full load respectively as compared to the emission of pure diesel fuel. Therefore, results show better combustion of fuel as compared to the pure diesel fuel. It shows that engine can work well and attain complete combustion. Chauhan et al. [2] studied on the performance and emission of a diesel engine fueled with Jatropha biodiesel oil and blends, and found lower $\mathrm{CO}_{2}$ emissions than a diesel engine.

\section{HC Emission}

Diesel engines emission behaviour is also represented by $\mathrm{HC}$ emission. Figure 7(b) presents the $\mathrm{HC}$ emissions of standard diesel and dual fuel blend of single cylinder constant speed (1500 RPM) diesel engine. The dual fuel blend exhibits higher HC emissions at all load conditions than pure diesel fuel. HC emission increased $88 \%, 44 \%$, $44.7 \%$, and $29 \%$ at no load to full load. This may be because of a higher density of the dual blend fuel that affects the spray entrancement [41]. Moreover, at low loads, the cooling effect of the charge played a significant role due to the low combustion temperatures [46]. However, at higher loads, the difference between HC emissions emanating from BT50 and that from the standard diesel fuel was smaller due to better combustion.

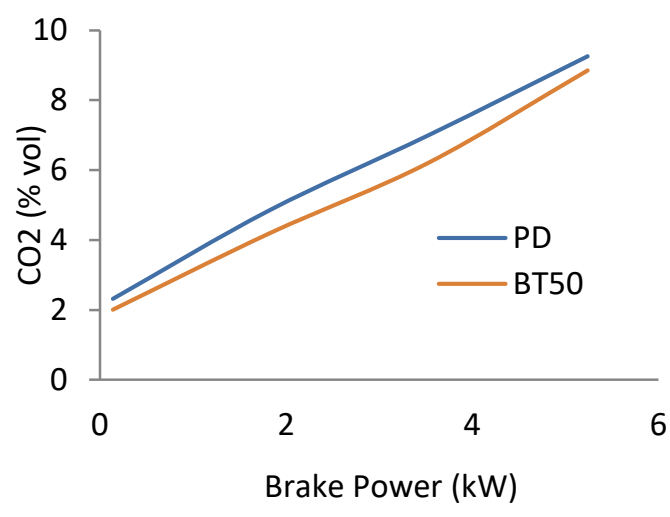

(a)

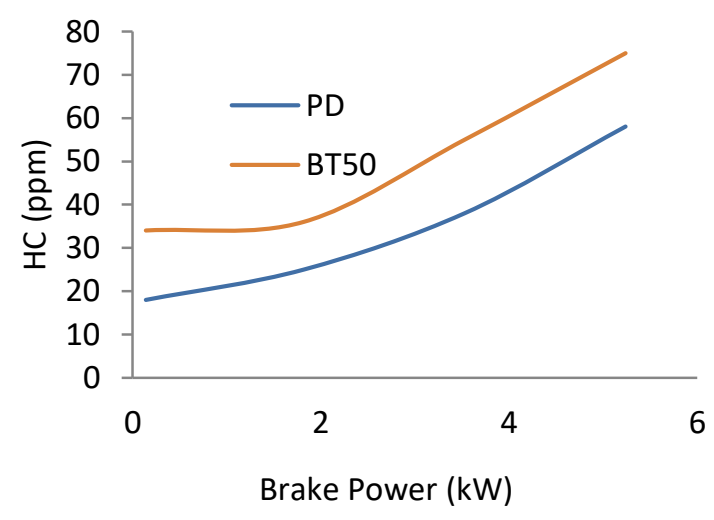

(b)

Figure 7. $\mathrm{CO}_{2}$ and $\mathrm{HC}$ emissions at different engine power.

\section{CONCLUSIONS}

The present work has tried to use the dual biofuel, Jatropha biodiesel and turpentine oil in a single cylinder and compression ignition diesel engine, and abolish the use of standard diesel completely without any amendment. The findings showed that the properties of both fuels are suitable and flattering for use in the diesel engine. The dual 
fuel blend was investigated and compared to the pure diesel on combustion, performance and emission characteristics of the engine. The salient points are as follows.

1. In the use of dual fuel blend (BT50), the engine operated successfully and smoothly and performed better; BSFC was higher and the BTE was lower (2.9\%) as compared to the conventional diesel fuel.

2. Regardless of the load conditions, the dual fuel blend BT50 gave lower $\mathrm{CO}_{2}, \mathrm{NOx}$, $\mathrm{CO}$ and higher $\mathrm{HC}$ emission as compared to the pure diesel fuel. Moreover, in full load condition, a reduction of $41.6 \%, 3 \%$ and $4.43 \%$ in $\mathrm{CO}, \mathrm{NOx}$, and $\mathrm{CO}_{2}$ respectively were recorded while $\mathrm{HC}$ was found to increase by $29.31 \%$.

3. The Jatropha methyl ester has a lower volatility and higher viscosity compared to the turpentine oil, which might have turpentine oil causing proper mixing and complete combustion; therefore, the dual fuel blend showed lower emissions.

Therefore, it can be concluded that the dual fuel blend (BT50) fuel oil can be considered as a promising source of biodiesel. The uses of Jatropha biodiesel and turpentine oil gave good performance and reduced emissions while increasing the HC emissions.

\section{ACKNOWLEDGEMENT}

The authors thanked Mr. Hradesh Kushwaha, a student of M.Tech, Thermal Engineering, MANIT, Bhopal for conducting the experiments. The experiments were performed at the heat engine laboratory, MANIT Bhopal, India, and the support for this research was provided by TEQIP-II.

\section{REFERENCES}

[1] Floater G, Rode P, Robert A, Kennedy C, Hoornweg D, Slavcheva R, et al. Cities and the New Climate Economy: the transformative role of global urban growth. 2014.

[2] Mahgoub BKM, Sulaiman SA, Abdul Karim ZA. Performance study of imitated syngas in a dual-fuel compression ignition diesel engine. International Journal of Automotive and Mechanical Engineering. 2015;11:2282-93.

[3] Adam IK, A. Aziz AR, Yusup S. Determination of diesel engine performance fueled biodiesel (rubber seed/palm oil mixture) diesel blend. International Journal of Automotive and Mechanical Engineering. 2015;11:2675-85.

[4] Kapilan N, Ashok Babu TP, Reddy RP. Improvement of performance of dual fuel engine operated at part load. International Journal of Automotive and Mechanical Engineering. 2010;2:200-10.

[5] Chauhan BS, Kumar N, Cho HM. A study on the performance and emission of a diesel engine fueled with Jatropha biodiesel oil and its blends. Energy. 2012;37:616-22.

[6] Paul G, Datta A, Mandal BK. An experimental and numerical investigation of the performance, combustion and emission characteristics of a diesel engine fueled with jatropha biodiesel. Energy Procedia. 2014;54:455-67.

[7] Vashist D, Ahmad M. Statistical analysis of diesel engine performance for castor and jatropha biodiesel-blended fuel. International Journal of Automotive and Mechanical Engineering. 2014;10:2155. 
[8] Nematizade P, Ghobadian B, Najafi G. Investigation of fossil fuels and liquid biofuels blend properties using artificial neural network. International Journal of Automotive and Mechanical Engineering. 2012;5:639-47.

[9] Yusaf T, Hamawand I, Baker P, Najafi G. The effect of methanol-diesel blended ratio on CI engine performance. International Journal of Automotive and Mechanical Engineering. 2013;8:1385.

[10] Nayak C, Pattanaik BP, Nayak SK. Effect of preheated jatropha oil and jatropha oil methyl ester with producer gas on diesel engine performance. International Journal of Automotive and Mechanical Engineering. 2014;9:1709-22.

[11] Mat Yasin MH, Mamat R, Sharma KV, Yusop AF. Influence of palm methyl ester (PME) as an alternative fuel in multicylinder diesel engine. Journal of Mechanical Engineering and Sciences. 2012;3:331-9.

[12] Jain S, Sharma M. Prospects of biodiesel from Jatropha in India: a review. Renewable and Sustainable Energy Reviews. 2010;14:763-71.

[13] Shukri MR, Rahman MM, Ramasamy D, Kadirgama K. Artificial neural network optimization modeling on engine performance of diesel engine using biodiesel fuel. International Journal of Automotive and Mechanical Engineering. 2015;11:2332-47.

[14] Sathiyamoorthi R, Sankaranarayanan G. Fuel injection timings of a direct injection diesel engine running on neat lemongrass oil-diesel blends. International Journal of Automotive and Mechanical Engineering. 2015;11:2348-63.

[15] Khalid A, Jaat N, Sapit A, Razali A, Manshoor B, Zaman I, et al. Performance and emissions characteristics of crude jatropha oil biodiesel blends in a diesel engine. International Journal of Automotive and Mechanical Engineering. 2015;11:2447-57.

[16] Agarwal AK. Biofuels (alcohols and biodiesel) applications as fuels for internal combustion engines. Progress in energy and combustion science. 2007;33:233-71.

[17] Karthikeyan R, Mahalakshmi N. Performance and emission characteristics of a turpentine-diesel dual fuel engine. Energy. 2007;32:1202-9.

[18] Kaplan C, Alma MH, Tutuş A, Çetinkaya M, Karaosmanoğlu F. Engine performance and exhaust emission tests of sulfate turpentine and No: 2 diesel fuel blend. Petroleum science and technology. 2005;23:1333-9.

[19] Liaquat A, Masjuki H, Kalam M, Bhuiya M, Varman M. Influence of coconut biodiesel and waste cooking oil blended fuels on engine performance and emission characteristics. ASME 2012 Internal Combustion Engine Division Fall Technical Conference: American Society of Mechanical Engineers; 2012. p. 16976.

[20] Bora BJ, Saha UK. Comparative assessment of a biogas run dual fuel diesel engine with rice bran oil methyl ester, pongamia oil methyl ester and palm oil methyl ester as pilot fuels. Renewable Energy. 2015;81:490-8.

[21] Campos-Fernández J, Arnal JM, Gómez J, Dorado MP. A comparison of performance of higher alcohols/diesel fuel blends in a diesel engine. Applied Energy. 2012;95:267-75.

[22] Abdul Adam A, Amir K, Bukhari M, Izzuddin Z. Performance and emissions characteristics of crude jatropha oil biodiesel blends in a diesel engine. International Journal of Automotive and Mechanical Engineering (IJAME). 2015;11:2447-57. 
[23] Mohsin R, Majid Z, Shihnan A, Nasri N, Sharer Z. Effect of biodiesel blends on engine performance and exhaust emission for diesel dual fuel engine. Energy Conversion and Management. 2014;88:821-8.

[24] Devan P, Mahalakshmi N. A study of the performance, emission and combustion characteristics of a compression ignition engine using methyl ester of paradise oil-eucalyptus oil blends. Applied Energy. 2009;86:675-80.

[25] Anand K, Sharma R, Mehta PS. Experimental investigations on combustion, performance and emissions characteristics of neat karanji biodiesel and its methanol blend in a diesel engine. Biomass and bioenergy. 2011;35:533-41.

[26] Vallinayagam R, Vedharaj S, Yang W, Lee P, Chua K, Chou S. Pine oil-biodiesel blends: A double biofuel strategy to completely eliminate the use of diesel in a diesel engine. Applied Energy. 2014;130:466-73.

[27] Yilmaz N, Sanchez TM. Analysis of operating a diesel engine on biodieselethanol and biodiesel-methanol blends. Energy. 2012;46:126-9.

[28] Hansen AC, Zhang Q, Lyne PW. Ethanol-diesel fuel blends-a review. Bioresource technology. 2005;96:277-85.

[29] Arpa O, Yumrutas R, Alma M. Effects of turpentine and gasoline-like fuel obtained from waste lubrication oil on engine performance and exhaust emission. Energy. 2010;35:3603-13.

[30] Hasan MM, Rahman MM, Kadirgama K. A review on homogeneous charge compression ignition engine performance using biodiesel-diesel blend as a fuel. International Journal of Automotive and Mechanical Engineering. 2015;11:2199211.

[31] Vashist D, Ahmad M. Statistical Analysis of Diesel Engine Performance for Castor and Jatropha Biodiesel-Blended Fuel. International Journal of Automotive and Mechanical Engineering. 2014;10:2155-69.

[32] Ghafoori M, Ghobadian B, Najafi G, Layeghi M, Rashidi A, Mamat R. Effect of nano-particles on the performance and emission of a diesel engine using biodieseldiesel blend. International Journal of Automotive and Mechanical Engineering. 2015;12:3097-108.

[33] Nguyen K-B, Dan T, Asano I. Effect of double injection on combustion, performance and emissions of Jatropha water emulsion fueled direct-injection diesel engine. Energy. 2015;80:746-55.

[34] Pramanik K. Properties and use of Jatropha curcas oil and diesel fuel blends in compression ignition engine. Renewable Energy. 2003;28:239-48.

[35] Agarwal D, Agarwal AK. Performance and emissions characteristics of Jatropha oil (preheated and blends) in a direct injection compression ignition engine. Applied Thermal Engineering. 2007;27:2314-23.

[36] Kandpal J, Madan M. Jatropha curcus: a renewable source of energy for meeting future energy needs. Renewable Energy. 1995;6:159-60.

[37] Chauhan BS, Kumar N, Du Jun Y, Lee KB. Performance and emission study of preheated Jatropha oil on medium capacity diesel engine. Energy. 2010;35:248492.

[38] Anand BP, Saravanan C, Srinivasan CA. Performance and exhaust emission of turpentine oil powered direct injection diesel engine. Renewable Energy. 2010;35:1179-84.

[39] Hasan MM, Rahman MM. Homogeneous charge compression ignition combustion: Advantages over compression ignition combustion, challenges and solutions. Renewable and Sustainable Energy Reviews. 2016; 57:282-91. 
[40] Yumrutaş R, Alma MH, Özcan H, Kaşka Ö. Investigation of purified sulfate turpentine on engine performance and exhaust emission. Fuel. 2008;87:252-9.

[41] Kumar MS, Ramesh A, Nagalingam B. An experimental comparison of methods to use methanol and Jatropha oil in a compression ignition engine. Biomass and Bioenergy. 2003;25:309-18.

[42] Achten W, Verchot L, Franken YJ, Mathijs E, Singh VP, Aerts R, et al. Jatropha bio-diesel production and use. Biomass and Bioenergy. 2008;32:1063-84.

[43] Banapurmath N, Tewari P, Hosmath R. Performance and emission characteristics of a DI compression ignition engine operated on Honge, Jatropha and sesame oil methyl esters. Renewable Energy. 2008;33:1982-8.

[44] Raheman H, Kumari S. Combustion characteristics and emissions of a compression ignition engine using emulsified jatropha biodiesel blend. Biosystems Engineering. 2014;123:29-39.

[45] Hoque N, Mourshed M, Das B. Performance and emission comparison of Karanja (pongamia pinnata), Pithraj (aphanamixis polystachya), Neem (azadira chtaindica) and Mahua (madhuca longofolia) seed oil as a potential feedstock for biodiesel production in Bangladesh. International Journal of Automotive \& Mechanical Engineering. 2015;12.

[46] Nguyen K-B, Dan T, Asano I. Combustion, performance and emission characteristics of direct injection diesel engine fueled by Jatropha hydrogen peroxide emulsion. Energy. 2014;74:301-8.

\section{NOMENCLATURE}

BSFC: Brake specific fuel consumption

BT50: Dual fuel blend (50\% Jatropha methyl ester and 50\% Turpentine oil)

BTE: Brake thermal efficiency

CO: Carbon mono oxide

$\mathrm{CO}_{2}$ : Carbon dioxide

DI: Direct injection

HC: Hydro carbon

NOx: Nitrogen oxides

$\mathrm{kW}$ : Kilo watt

ppm: Parts per million

$\%$ vol: Percentage volume

cc: cubic centimetre

PD: pure diesel

deg: Degree

CA: crank angle 